УДК 663.9

DOI https://doi.org/10.37734/2518-7171-2021-1-10

\title{
ДОСЛІДЖЕННЯ АСОРТИМЕНТУ ТА ПОКАЗНИКІВ ЯКОСТІ I БЕЗПЕЧНОСТІ КРУП
}

\author{
А. С. ТКАЧЕНКО, кандидат технічних наук, доцент \\ (Вищий навчальний заклад Укоопспілки «Полтавський університет економіки і торгівлі»); \\ Л. М. ГУБА, кандидат технічних наук, доцент \\ (Вищий навчальний заклад Укоопспілки «Полтавський університет економіки і торгівлі»);
}

А. І. МОТОРНА (Вищий навчальний заклад Укоопспілки

«Полтавський університет економіки і торгівлі»)

\begin{abstract}
Анотація. У статті досліджено сучасний асортимент круп. Найбільшими виробниками круп в Україні є "Cereal Planet Ukraine», «Tерра», «HD-груn», «ГалаФудз», "Сто пудів», «Хуторок». Об’єктом дослідження показників якості та безпечності вибрані крупи ТМ «Гадячанка». Для дослідження використовувалися класичні методи: вологість визначали висушуванням до постійної маси; визначення металомагнітних домішок здійснювали методом їх відділення магнітом вручну і подальшому зважуванні та вимірюванні їх частинок; дослідження забрудненості шкідниками проводили за допомогою просіювання через сито; вивчення наявності токсичних металів відбувалося з використанням атомно-абсорбційного спектрофотометра. Маркування продукиії визначали на відповідність вітчизняному законодавству. Подальші дослідження планується присвятити науковим підходам до розроблення системи НАССР для виробництва круп.
\end{abstract}

Ключові слова: крупи, вологість, металомагнітні домішки, шкідники, маркування.

Постановка проблеми у загальному вигляді. Круп'яні культури є стратегічними продуктами у забезпеченні продовольчої безпеки, що відрізняються серед інших стабільним широким попитом і споживанням завдяки своїй високій поживності та ціновій доступності для всіх верств населення. В умовах пандемії коронавірусу і світової економічної кризи спостерігається зростання попиту на круп'яні культури на внутрішньому та зовнішньому агропродовольчих ринках [1]. Природнокліматичні умови України дозволяють у достатній кількості вирощувати зернові культури. Такий потенціал дозволяє не лише забезпечити внутрішні потреби ринку, а й експортувати зернову продукцію за кордон [2]. Проте для виробників важливим фактором успішної діяльності є врахування вітчизняних та закордонних вимог до безпечності та якості продукції.

Аналіз останніх досліджень і публікацій. Круп'яні культури $є$ стратегічними продуктами у забезпеченні продовольчої безпеки. Згідно 3 діючою номенклатурою, в Україні виробляють 7 видів круп, при цьому із одного виду зерна переробні підприємства виготовляють декілька їх видів: із гречки - ядрицю і подрібнену, із ячменю - ячмінну і перлову, із пшениці - пшеничну та манну. Споживчою нормою в Україні встановлено річне споживання круп однією працездатною людиною на рівні 7,1 кг [3].

Динаміка об'єму круп на душу населення за 2018-10 міс. 2020 рр. в Україні наведена на рис. 1 (за даними Компанії Pro-Consulting 3 посиланням на Державну службу статистики).
Як видно з рис. 1, у 2020 році несуттєво збільшилися обсяги перлової і ячної крупи на душу населення, тоді як обсяги пшеничної і горохової круп зменшилися. За результатами аналізу ринку круп в Україні можна зробити висновок, що для суттєвого збільшення внутрішнього споживання такого виду продукції у середньостроковій перспективі немає підстав [5].

За даними [6] структура виробництва основних видів круп підприємствами України у 2019 році була розподілена, як показано на рис. 2 .

Формування цілей статті. Мета полягає у дослідженні асортименту круп'яної індустрії України та показників якості круп ТМ «Гадячанка».

Виходячи 3 поставленої мети, завдання дослідження:

- проаналізувати ринок круп'яної індустрії в Україні;

- здійснити аналіз маркування на відповідність законодавству круп ТМ «Гадячанка»;

- експериментально дослідити показники якості і безпечності круп ТМ «Гадячанка».

Об'єкт та предмет дослідження. Об'єкт дослідження - крупи горохова, ячмінна, пшенична ТМ «Гадячанка». Предмет дослідження - дослідження показників якості та безпечності круп ТМ «Гадячанка» пшенична Полтавська № 2 та ячмінна перлова (рис. 3).

Крупи виготовляються відповідно до національних стандартів. Усі крупи розфасовані у пакування з ВОРР плівок масою 750 г. Термін придатності - не більше 12 місяців.

(C) Ткаченко А. С., Губа Л. М., Моторна А. І., 2021 
Динаміка об'єму круп на душу населення за 2018-10 міс. 2020 рp. в Україні

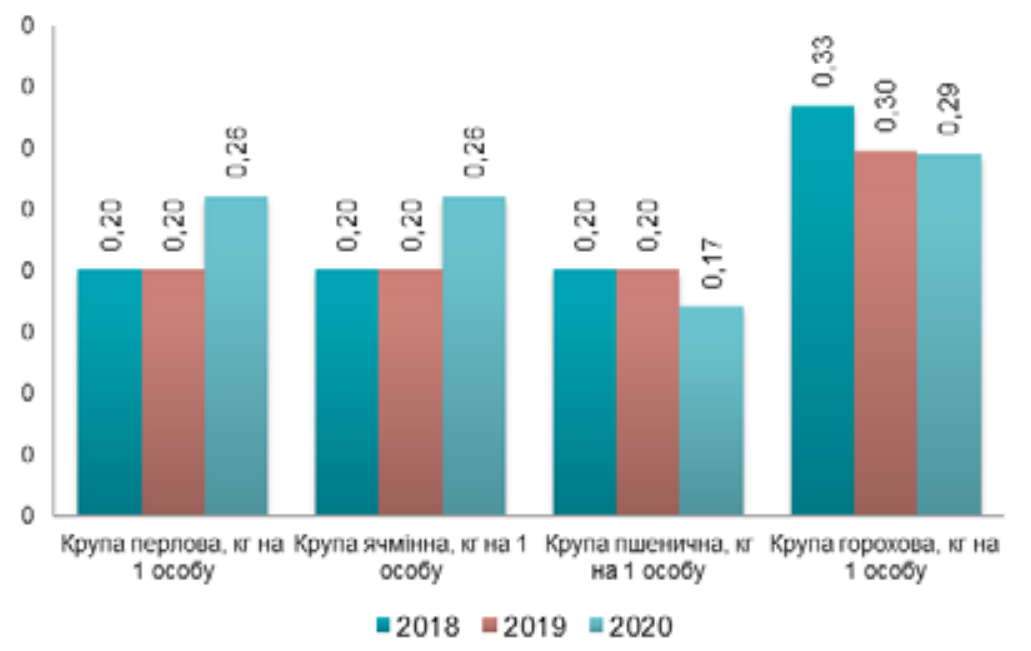

Рис. 1. Динаміка об’єму круп на душу населення за 2018-10 міс. 2020 pp. [4]

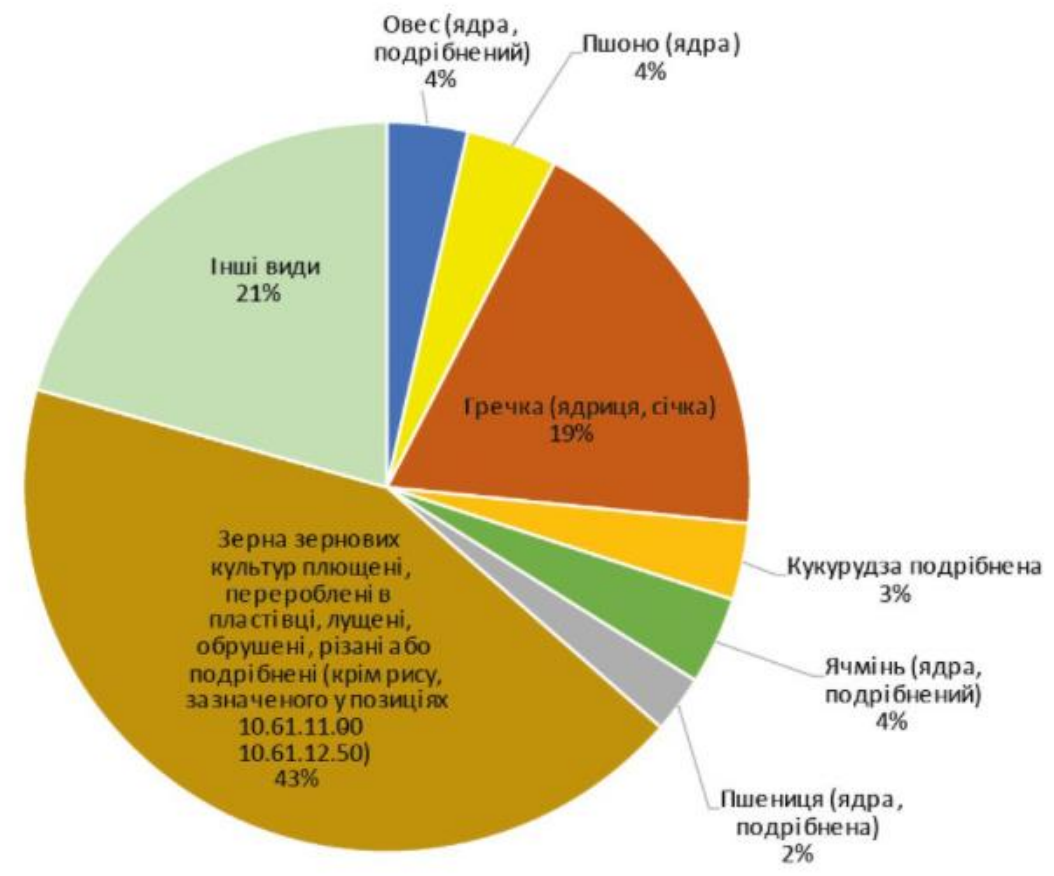

Рис. 2. Структура виробництва основних видів круп підприсмствами України у 2019 році [6]

Результати дослідження. Для дослідження ринку круп було використано метод аналізу внутрішньої та зовнішньої вторинної інформації. 3 метою дослідження показників якості та безпечності круп були використані методи: вологість визначали методом висушування 10 г розмеленої крупи у сушильній шафі. Визначення металомагнітних домішок здійснювали методом їx виділення магнітом вручну і подальшому зважуванні та вимірюванні їх частинок. Дослідження забрудненості шкідниками проводили за допомогою просіювання через сито 3 діаметром отворів не більше 1,6 мм та огляду сита під лупою. Вивчення наявності токсичних металів відбувалося 3 використанням атомно-абсорбційного спектрофотометра [7; 8].

Дослідження асортименту круп. Найбільшими виробниками круп в Україні $\epsilon$ «Cereal Planet Ukraine», «Терра», «HD-груп», «ГалаФудз», «Сто пудів», «Хуторок» [9]. 


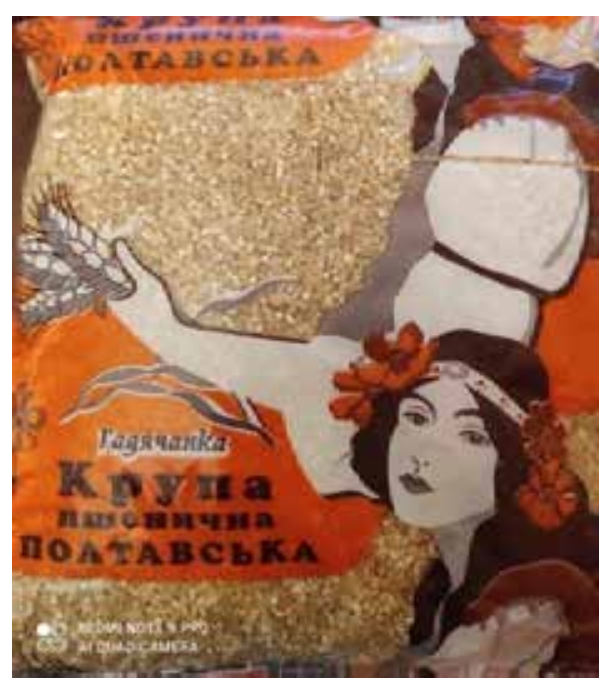

Рис. 3. Крупа ТМ «Гадячанка»

Cereal Planet Ukraine - продукція компанії постачається по всій Україні та нині займає до $10 \%$ українського ринку круп. Під цим брендом компанія виробляє вагову крупу для В2В, під ТМ «ОЛІМП» - чотири товарні лінії - «Булгур», «Рідлана», «Майфайна», «Златокосиця», під ТМ «Люба ферма» - комбікорми. Продукція ТМ «Олімп» представлена на рис. 4.
Компанія «ТЕРРА» виробляє натуральні продукти харчування на основі зернових, а також бобових культур з 1998 року. Асортимент круп становить: каші солодкі; каші солоні; каші з екстрактами; гранола дой-пак; гранола стаканчик; пластівці в крафт-пакеті; пластівці «Plus» у крафт-пакеті; пластівці; крупи у варильному пакеті. Продукція такого виробника представлена на рис. 5 .

Компанія «ГалаФудз» - лідер на ринку фасування бакалійної продукції в Україні. Працюючи з 2015 року компанія виготовляє продукцію для «Сільпо», «METRO C\&C», «Ашан», «Велика Кишеня» та ін., які випускають власну продукцію (Private Label).

Торговельна марка «Сто пудів» представляє традиційні та інноваційні продукти для смачного, зручного та корисного харчування. Уже 15 років ТМ «Сто пудів», користуючись класичними і національними рецептами, в процесі придумуючи свої способи приготування, удосконалює і виробляє продукти для людей з різними вподобаннями в харчуванні. Лінійка круп представлена такими: «Дача», «Економ», «Міні», «Преміум», «Традиційна». Виробник пропонує крупи: гречану, рисову, пшоно, манну, пшеничну, булгур, кус-кус, кукурудзяну, ячмінну, вівсяну. Продукція ТМ «Сто пудів» представлена на рис. 6.
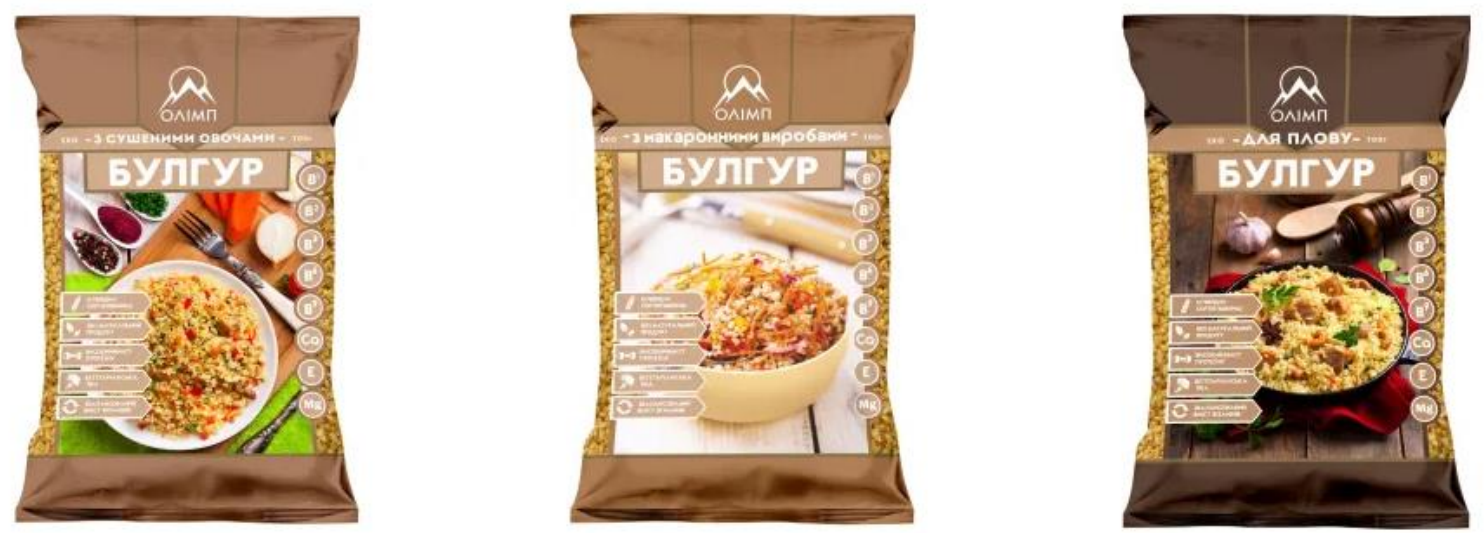

Рис. 4. Крупа «Булгур» ТМ «Олімп» (виробник - Cereal Planet Ukraine)
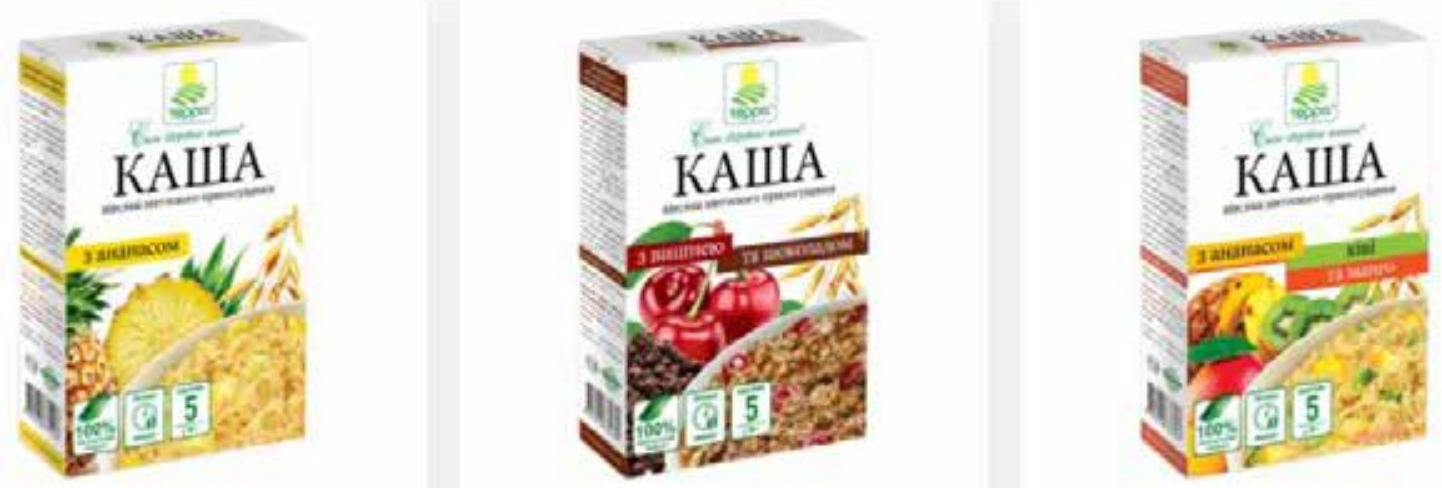

Рис. 5. Каші вівсяні миттєвого приготування (виробник - «Терра») 
ТМ «Хуторок» представлена такими продуктами, як: борошно та крупи, макарони, соуси зі стиглих томатів, овочева та грибна консервація, гірчиця, хрін, спеції. Крупи ТМ «Хуторок» презентовані на рис. 7.

Особливого розвитку набуває ринок органічних круп [10]. Щороку збільшується обсяг виробництва органічних харчових продуктів. В Україні представлені органічні торгові марки круп «Сквирянка», «Агроекологія», «Козуб».

Отже, ринок круп в Україні досить різноманітний та представлений як традиційними, так і органічними продуктами. Найбільшими виробниками круп в Україні $\epsilon$ «Cereal Planet Ukraine», «Терра», «НD-груп», «ГалаФудз», «Сто пудів», «Хуторок».

Відповідно до [11] маркування слова, описи, знаки для товарів і послуг (торговельні марки), графічні зображення або символи, що стосуються харчових продуктів, які розміщуються на будьякій упаковці, етикетці (стікері), кольєретці, а за відсутності упаковки у документі або повідомленні, що супроводжують харчовий продукт або посилаються на нього. Аналіз маркування крупи пшеничної Полтавської № 2 ТМ «Гадячанка» наведено у таблиці 1.

Отже, аналіз маркування крупи дає підстави вважати, що виробнику слід звернути увагу на маркування алергенів, як це вимагається законодавством.
Результати дослідження показників якості та безпечності круп ТМ «Гадячанка» наведено у таблицях 2-4.

За даними таблиці крупа відповідає за показниками вологості, токсичних елементів та пестицидів вимогам нормативної документації. Вологість становить $8,8 \%$, вміст міді - 0,12 мг/кг. Металомагнітних домішок та шкідників не виявлено, що також відповідає вимогам до якості круп.

За даними таблиці крупа відповідає за показниками вологості, токсичних елементів та пестицидів вимогам нормативної документації. Вологість становить $6,4 \%$, вміст міді - 0,2 мг/кг. Металомагнітних домішок та шкідників не виявлено, що також відповідає вимогам до якості круп.

За даними таблиці крупа відповідає за показниками вологості, токсичних елементів та пестицидів вимогам нормативної документації. Вологість становить 5,4\%, вміст міді - 0,24 мг/кг. Металомагнітних домішок та шкідників не виявлено, що також відповідає вимогам до якості круп.

Отже, крупи ТМ «Гадячанка» відповідають нормативним документам за показниками якості i безпечності.

Висновки. Ринок круп в Україні досить різноманітний та представлений як традиційними, так і органічними продуктами. Найбільшими виробниками круп в Україні є «Cereal Planet Ukraine», «Терра», «НD-груп», «ГалаФудз», «Сто пудів»,
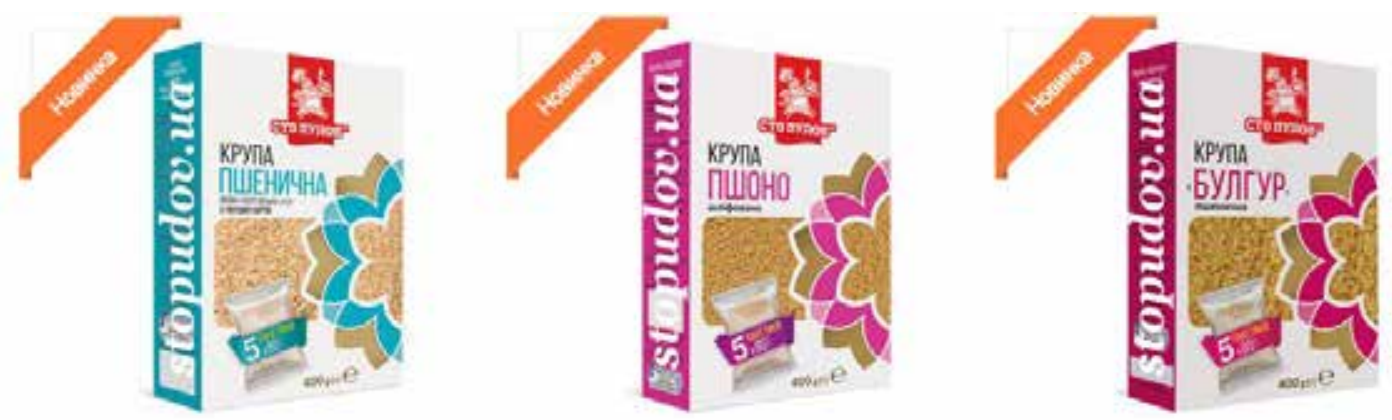

Рис. 6. Продукція ТМ «Сто пудів»
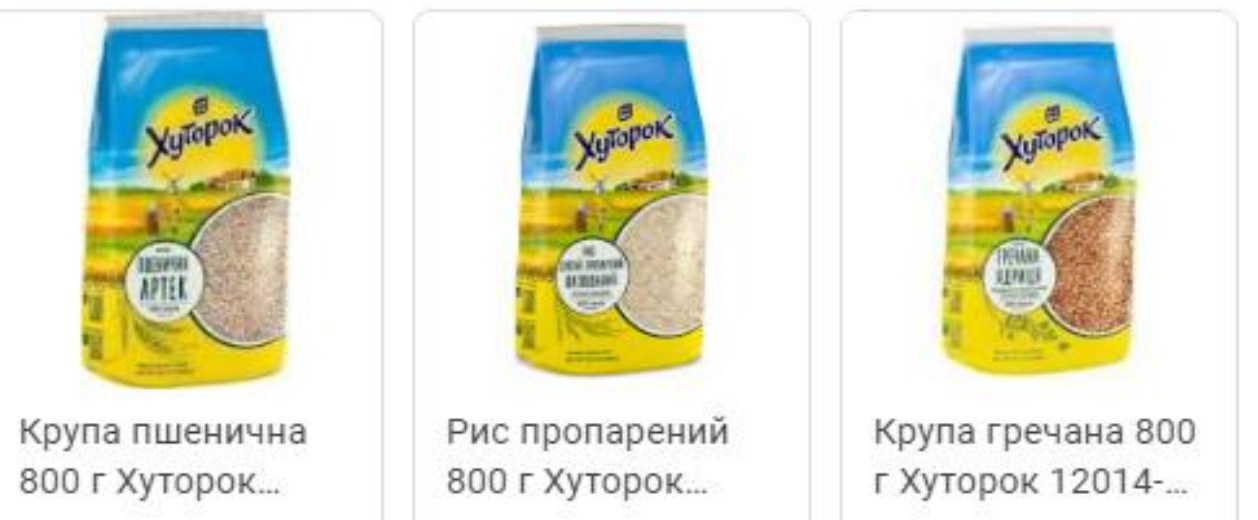

Рис. 7. Продукція ТМ «Хуторок» 
«Хуторок». Аналіз маркування крупи пшеничної Полтавська № 2 ТМ «Гадячанка» дає підстави вважати, що виробнику слід звернути увагу на маркування алергенів, як це вимагається законодавством, та зазначати вміст глютена на маркуванні. Крупи ТМ «Гадячанка» відповідають нормативним документам за показниками якості i безпечності. У крупі пшеничній Полтавській
№ 2 вологість становить 8,8\%, вміст міді 0,12 мг/кг. Вологість гороху лущеного колотого становить 5,4\%, вміст міді-0,24 мг/кг. Вологість крупи ячмінної перлової становить $6,4 \%$, вміст міді - 0,2 мг/кг. Металомагнітних домішок та шкідників не виявлено у жодному зразку круп. Кількість пестицидів у всіх зразках нижча за чутливість приладу.

Таблиця 1

Аналіз відповідності маркування крупи пшеничної Полтавської № 2 ТМ «Гадячанка» чинному законодавству

\begin{tabular}{|l|l|}
\hline \multicolumn{1}{|c|}{ Елемент обов'язкової інформації на маркуванні } & $\begin{array}{c}\text { Крупа пшенична Полтавська } \\
\text { № 2 ТМ «Гадячанка» }\end{array}$ \\
\hline 1. Назва харчового продукту & $\begin{array}{l}\text { Крупа пшенична Полтавська } \\
\text { № 2 ТМ «Гадячанка»» }\end{array}$ \\
\hline 2. Перелік інгредієнтів & Зазначено \\
\hline $\begin{array}{l}\text { 3. Будь-які інгредієнти або допоміжні матеріали для переробки, які } \\
\text { використовуються у виробництві або приготуванні харчового продукту та } \\
\text { залишаються присутніми у готовому продукті, навіть у зміненій формі }\end{array}$ & Не застосовується \\
\hline $\begin{array}{l}\text { 4. Кількість певних інгредієнтів або категорій інгредієнтів } \\
\text { 5. Кількість харчового продукту в установлених одиницях вимірювання }\end{array}$ & $\begin{array}{l}\text { Не зазначено, що крупа містить } \\
\text { глютен }\end{array}$ \\
\hline 6. Мінімальний термін придатності або дата «вжити до» & Маса нетто 750 г \\
\hline $\begin{array}{l}\text { 7. Будь-які особливі умови зберігання та/або умови використання (за потреби) } \\
\text { Зазначена }\end{array}$ & $\begin{array}{l}\text { Зазначена вологість і термін } \\
\text { зберігання }\end{array}$ \\
\hline 8. Найменування та місцезнаходження оператора ринку харчових продуктів & Зазначено \\
\hline 9. Країна походження або місце походження & Україна \\
\hline $\begin{array}{l}\text { 10. Інструкції з використання у разі якщо відсутність таких інструкцій } \\
\text { ускладнює належне використання харчового продукту }\end{array}$ & Зазначено \\
\hline $\begin{array}{l}\text { 11. Для напоїв із вмістом спирту етилового понад 1,2\% об’ємних одиниць - } \\
\text { фактичний вміст спирту в напої }\end{array}$ & Не застосовується \\
\hline \begin{tabular}{l} 
12. Інформація про поживну цінність харчового продукту \\
\hline
\end{tabular} & $\begin{array}{l}\text { Інформацію про білки, жири та } \\
\text { вуглеводи зазначено }\end{array}$ \\
\hline
\end{tabular}

Таблиця 2

Результати дослідження показників якості і безпечності крупи пшеничної Полтавська № 2 відповідно до ДСТУ 7699:2015

\begin{tabular}{|l|l|l|l|}
\hline \multicolumn{1}{|c|}{ Назва показників } & \multicolumn{1}{|c|}{$\begin{array}{c}\text { Виявлена } \\
\text { концентрація }\end{array}$} & \multicolumn{1}{|c|}{$\begin{array}{c}\text { Одиниці } \\
\text { вимірювання }\end{array}$} & $\begin{array}{c}\text { Норма відповідно } \\
\text { до нормативно-технічної } \\
\text { документації }\end{array}$ \\
\hline Масова частка вологи & 8,8 & $\%$ & не більше $14 \%$ \\
\hline Металомагнітні домішки & не виявлено & мг/кг & не більше $3 \mathrm{mг} /$ кг \\
\hline Забрудненість шкідниками зерна & не виявлено & \multicolumn{1}{c|}{-} & не допускаєься \\
\hline Токсичні елементи: мідь & 0,12 & мг/кг & не більше $5 \mathrm{mг/ \kappa г}$ \\
\hline Пестициди: $2,4-Д$ & мг/кг & не більше $0,2 \mathrm{мг} /$ кг \\
\hline
\end{tabular}

Таблиця 3

Результати дослідження показників якості і безпечності крупи ячмінної перлової відповідно до ДСТУ 7700:2015

\begin{tabular}{|c|c|c|c|}
\hline Назва показників & $\begin{array}{c}\text { Виявлена } \\
\text { концентрація }\end{array}$ & $\begin{array}{c}\text { Одиниці } \\
\text { вимірювання }\end{array}$ & $\begin{array}{c}\text { Норма відповідно } \\
\text { до нормативно-технічної } \\
\text { документації } \\
\end{array}$ \\
\hline Масова частка вологи & 6,4 & $\%$ & не більше $15 \%$ \\
\hline Металомагнітні домішки & не виявлено & $\mathrm{M \Gamma} / \mathrm{К} \Gamma$ & не більше 3 мг/кг \\
\hline Забрудненість шкідниками зерна & не виявлено & - & не допускається \\
\hline Токсичні елементи: мідь & 0,2 & МГ/КГ & не більше 5 мг/кг \\
\hline Пестициди: 2,4-Д & < чут. метода & МГ/КГ & не більше 0,2 мг/кг \\
\hline
\end{tabular}


Таблиця 4

Результати дослідження показників якості і безпечності крупи гороху лущеного колотого відповідно до ДСТУ 7701:2015

\begin{tabular}{|c|c|c|c|}
\hline Назва показників & $\begin{array}{c}\text { Виявлена } \\
\text { концентрація }\end{array}$ & $\begin{array}{c}\text { Одиниці } \\
\text { вимірювання }\end{array}$ & \begin{tabular}{|c|} 
Норма відповідно \\
до нормативно-технічної \\
документації
\end{tabular} \\
\hline Масова частка вологи & 5,4 & $\%$ & не більше $15 \%$ \\
\hline Металомагнітні домішки & не виявлено & МГ/КГ & не більше 3 мг/кг \\
\hline Забрудненість шкідниками зерна & не виявлено & - & не допускається \\
\hline Токсичні елементи: мідь & 0,24 & МГ/КГ & не більше 5 мг/кг \\
\hline Пестициди: 2,4-Д & $<$ чут. метода & МГ/КГ & не більше 0,2 мг/кг \\
\hline
\end{tabular}

\section{СПИСОК ВИКОРИСТАНИХ ДЖЕРЕЛ}

1. Ринок круп'яних культур у 2020 році: аналітика та прогнози / Економічний гектар. URL: http://agrobusiness.com.ua/agro/ekonomichnyi-hektar/item/17395-rynok-krupianykh-kultur-u-2020-rotsi-analityka-ta-prohnozy. html (дата звернення: 10.01.2022).

2. Лавринчук О.В. Перспективи розвитку ринку зерна України. Облік і фінанси АПК : освітній портал. 2011. № 3. C. 144-152.

3. Пенькова О. Тенденції та перспективи розвитку ринку круп'яних виробів в України / О. Пенькова, А. Харенко, Ю. Цимбалюк. Науковий вісник Мукачівського державного університету. 2020. № 1, С. 38-44.

4. Аналіз ринку круп України 2020. URL: https://pro-consulting.ua/ua/issledovanie-rynka/analiz-rynka-krupukrainy-2020-god (дата звернення: 10.01.2022).

5. Калашник О.В. Якість крупи гречаної, імпортованої в України / О.В. Калашник, С.Е. Мороз, О.В. Бараболя та ін. Вісник Полтавської державної аграрної академї̈, 2019. (2), С. 28-38. URL: https://doi.org/10.31210/ visnyk2019.02.03.

6. Виробникам круп в Україні варто переорієнтовуватися на експорт. URL: https://agravery.com/uk/posts/show/ virobnikam-krup-v-ukraini-varto-pereorientovuvatisa-na-eksport-eksperti (дата звернення: 10.01.2022).

7. Averchev. O. Analysis of economic aspects of buckwheat, panicum and rice growing and production in central and Eastern Europe and Ukraine / O. Averchev, H. Fesenko. Baltic Journal of Economic Studies. 2019. Vol. 5, No. 5. P. 213-221.

8. Gwirtz J.A. Processing maize flour and corn meal food products / Gwirtz J.A., Garcia Casal M.N. Annals of the New York Academy of Sciences. 2014. Vol. 1312, No. 1. P. 66-75.

9. Suri D. Effects of Different Processing Methods on the Micronutrient and Phytochemical Contents of Maize / D. Suri, J., Tanumihardjo. From A to Z. Comprehensive Reviews in Food Science and Food Safety. 2016. Vol. 15, No. 5. P. 912-926. URL: https://doi.org/10.1111/1541.

10. Про інформацію для споживачів щодо харчових продуктів : Закон України від 06.12.2018 № 2639-VIII. URL: https://zakon.rada.gov.ua/laws/show/2639-19\#Text (дата звернення: 10.01.2022).

11. Willer H. \& Lernoud J. The World of Organic Agriculture. Statistics and Emerging trends. FiBL\&IFOAM Organic International. Germany: Medienhaus Plump. 2018.

\section{REFERENCES}

1. Rynok krup'ianykh kultur u 2020 rotsi: analityka ta prohnozy. Ekonomichnyi hektar [Cereal market in 2020: analysis and forecasts. Economic hectare]. Retrieved from: http://agro-business.com.ua/agro/ekonomichnyi-hektar/ item/17395-rynok-krupianykh-kultur-u-2020-rotsi-analityka-ta-prohnozy.html [in Ukrainian].

2. Lavrynchuk, O. (2014). Perspektyvy rozvytku rynku zerna Ukrayiny [Prospects for the development of the grain market of Ukraine]. Oblik $i$ finansy APK: osvitniy portal - Accounting and Finance of AIC: educational portal, 3, 144-152 [in Ukrainian].

3. Penkova, O., Kharenko, A., Tsymbalyuk, Yu. (2020). Tendentsiyi ta perspektyvy rozvytku rynku krup'yanykh vyrobiv v Ukrayiny [Tendencies and prospects of development of the market of cereals in Ukraine]. Naukovyy visnyk Mukachivs 'koho derzhavnoho universytetu - Scientific Bulletin of Mukachevo State University, 1, 38- 44 [in Ukrainian].

4. Analysis of the cereals market of Ukraine 2020 [Analysis of the cereals market of Ukraine 2020]. Retrieved from: https://pro-consulting.ua/ua/issledovanie-rynka/analiz-rynka-krup-ukrainy-2020-god [in Ukrainian].

5. Kalashnyk, O., Moroz, S, Barabolya, O. at al. (2019). Yakist krupy hrechanoyi, importovanoyi v Ukrayiny [Quality of buckwheat imported in Ukraine]. Visnyk Poltavs 'koyi derzhavnoyi ahrarnoyi akademiyi - Bulletin of the Poltava State Agrarian Academy, (2), 28-38 [in Ukrainian].

6. Producers of cereals in Ukraine should refocus on exports [Producers of cereals in Ukraine should refocus on exports]. Retrieved from: https://agravery.com/uk/posts/show/virobnikam-krup-v-ukraini-varto-pereorientovuvatisa-naeksport-eksperti [in Ukrainian].

7. Averchev, O. (2019). Analysis of economic aspects of buckwheat, panicum and rice growing and production in central and Eastern Europe and Ukraine. Baltic Journal of Economic Studies, Vol. 5, 5, 213-221 [in English]. 
8. Gwirtz, J.A., Garcia Casal, M.N. (2014). Processing maize flour and corn meal food products. Annals of the New York Academy of Sciences, 1312, 66-75 [in English].

9. Suri D., Tanumihardjo, J. (2016). Effects of Different Processing Methods on the Micronutrient and Phytochemical Contents of Maize. From A to Z. Comprehensive Reviews in Food Science and Food Safety, 15, $912-926$ [in English].

10. On information for consumers on food: Law of Ukraine of 06.12.2018 № 2639-VIII [Pro informatsiiu dlia spozhyvachiv shchodo kharchovykh produktiv : Zakon Ukrainy vid 06.12.2018 No. 2639-VIII]. Retrieved from: https:// zakon.rada.gov.ua/laws/show/2639-19\#Text [in Ukrainian].

11. Willer, H. \& Lernoud, J. (2018). The World of Organic Agriculture. Statistics and Emerging trends. FiBL\&IFOAM - Organic International. Germany: Medienhaus Plump [in English].

A. Tkachenko, PhD, Associated Professor (Poltava University of Economics and Trade); L. Guba, PhD, Associated Professor (Poltava University of Economics and Trade); A. Motorna (Poltava University of Economics and Trade). Research of assortment and quality and safety indicators of cereals.

Abstract. The cereal market in Ukraine is quite diverse and is represented by both traditional and organic products. The largest producers of cereals in Ukraine are: "Cereal Planet Ukraine”, "Terra”, "HD-groups", "GalaFoods", "One hundred poods", "Khutorok". Analysis of the labeling of wheat groats Poltavska No. 2 TM "Gadyachanka" gives reason to believe that the manufacturer should pay attention to the labelling of allergens, as required by law and indicate the gluten content on the label. Groats of TM "Gadyachanka" correspond to regulatory documents on indicators of quality and safety. In wheat groats Poltavska No. 2 humidity is $8.8 \%$, copper content $-0.12 \mathrm{mg} / \mathrm{kg}$. Humidity of shelled peas is $5.4 \%$, copper content $-0.24 \mathrm{mg} / \mathrm{kg}$. Humidity of barley pearl barley is $6.4 \%$, copper content $-0.2 \mathrm{mg} / \mathrm{kg}$. Metal-magnetic impurities and pests were not detected in any sample of cereals. The amount of pesticides in all samples is lower than the sensitivity of the device. Further research is planned to be devoted to the scientific aspects of the implementation of the food safety management system based on the principles of HACCP in the production of cereals.

Key words: cereals, moisture, metal-magnetic impurities, pests, labelling. 